\title{
Avian influenza $A(\mathrm{H} 10 \mathrm{~N} 7)$ virus involvement in mass mortality of harbour seals (Phoca vitulina) in Sweden, March through October 2014
}

S Zohari (siamak.zohari@sva.se)1, A Neimanis², T Härkönen³, C Moraeus³, J F Valarcher ${ }^{1}$

1. Department of Virology, Immunobiology and Parasitology, National Veterinary Institute, Uppsala, Sweden

2. Department of Pathology and Wildlife Diseases, Wildlife Section, National Veterinary Institute, Uppsala, Sweden

3. Department of Environmental Research and Monitoring, Swedish Museum of Natural History, Stockholm, Sweden

Citation style for this article:

Zohari S, Neimanis A, Härkönen T, Moraeus C, Valarcher JF. Avian influenza A(H10N7) virus involvement in mass mortality of harbour seals (Phoca vitulina) in

Sweden, March through October 2014. Euro Surveill. 2014;19(46):pii=20967. Available online: http://www.eurosurveillance.org/ViewArticle.aspx?Articleld=20967

Article submitted on 12 November 2014 / published on 20 November 2014

We provide the first scientific report of influenza $A$ virus involvement in a mass mortality event among harbour seals (Phoca vitulina) off the west coast of Sweden. Avian influenza A $\left(\mathrm{H}_{10} \mathrm{~N}_{7}\right)$ virus was detected in the lungs of two affected animals. This subtype has not been reported in seals to date, nor has influenza A-associated mortality been reported in seals in Europe. Circulation of avian influenza viruses in mammals may have implications for public health.

\section{Background}

Increased numbers of dead harbour seals (Phoca vitulina) from the west coast of Sweden were first noted in March 2014. From March through October, 425 carcasses were detected in several seal colonies in the Kattegat and the Skagerrak seas (Figure 1). This unusually high mortality contrasted with the typical annual number of 30 to 40 dead seals reported from this area. Although most seals were too decomposed for examination, influenza A virus (IAV) subtype H10N7

\section{FIGURE 1}

Cumulative numbers of dead stranded harbour seals (Phoca vitulina) along the west coast of Sweden, March-October 2014 $(n=425)$

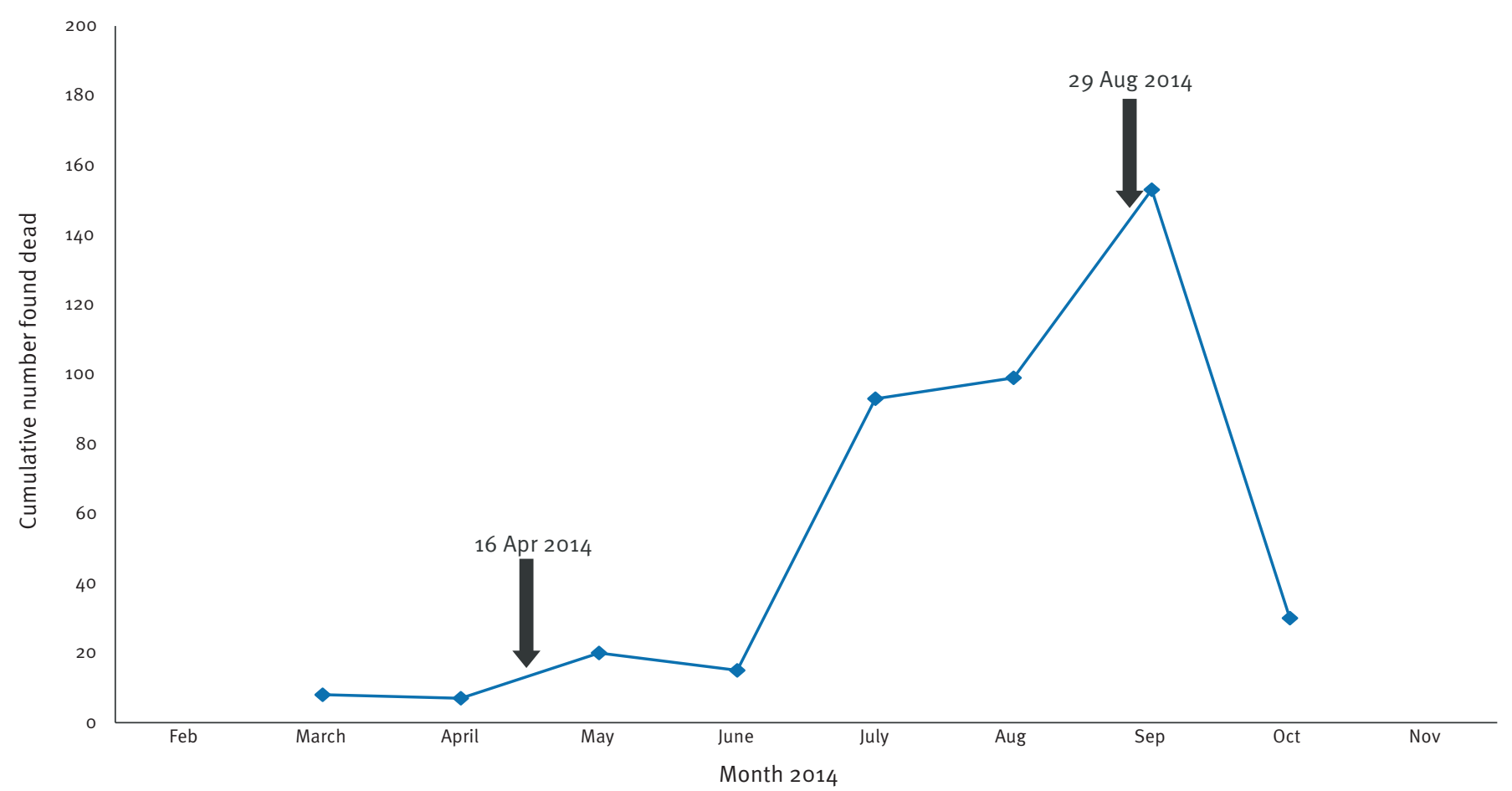

The arrows indicate the dates of sampling of the inuenza A positive seals. 
Phylogenetic relationship between haemagglutinin genes of $\mathrm{H} 10$ of influenza A virus subtypes
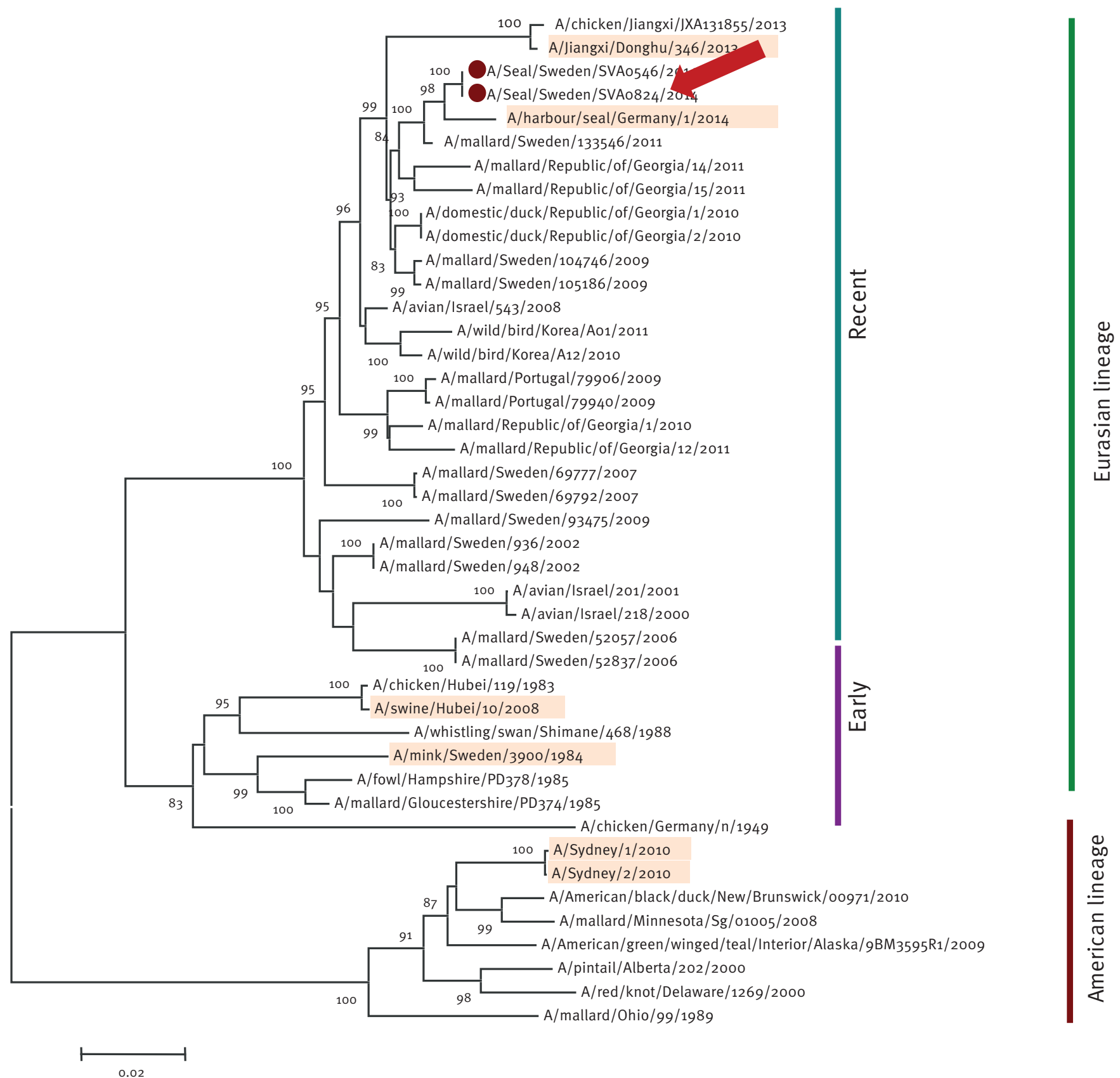

The protein coding region tree was generated by neighbour-joining analysis with the Tamura-Nei $\gamma$-model, using MEGA 6.o. Numbers below key nodes indicate the percentage of bootstrap values of 2,000 replicates. Isolates sequenced in this study are indicated by a red dot. Taxons leading to $\mathrm{A}\left(\mathrm{H}_{10}\right)$ subtype viruses detected in mammalian species are highlighted in pink. The nucleotide sequences obtained in the present study are available in the Global Initiative on Sharing All Influenza Data (GISAID) under HA gene accession numbers EPI545212 (Seal 1) and $\mathrm{EPI}_{547696}$ (Seal2). For the phylogenetic analysis, relevant sequences were obtained from the influenza database of the National Center for Biotechnology Information (NCBI), and the HA and NA genes of A/harbour seal/Germany/1/2014/H10N7 were obtained from GISAID's EpiFlu database.

was detected in the lungs of two animals. According to media reports [1], $\mathrm{H}_{10} \mathrm{~N}_{7}$ virus has recently been detected in dead seals in Denmark, Germany and the Netherlands in association with die-offs of seals first observed in July in Denmark and currently ongoing in Germany and the Netherlands [2,3].

\section{Case descriptions}

Seal 1 was observed suffering from buoyancy problems and respiratory distress off the coast of Gate Klova, Halland province. It was euthanised on 16 April, 2014 and examined by necropsy at the Swedish Museum of Natural History. Fresh and formalin-fixed tissues were submitted to the Swedish National Veterinary Institute (SVA) for further examination. Seal 2 was found dead on 29 August, 2014 in Beateberg, Västra Götaland 


\section{FIGURE 3}

Phylogenetic relationship between neuraminidase genes of N7 influenza A virus subtypes

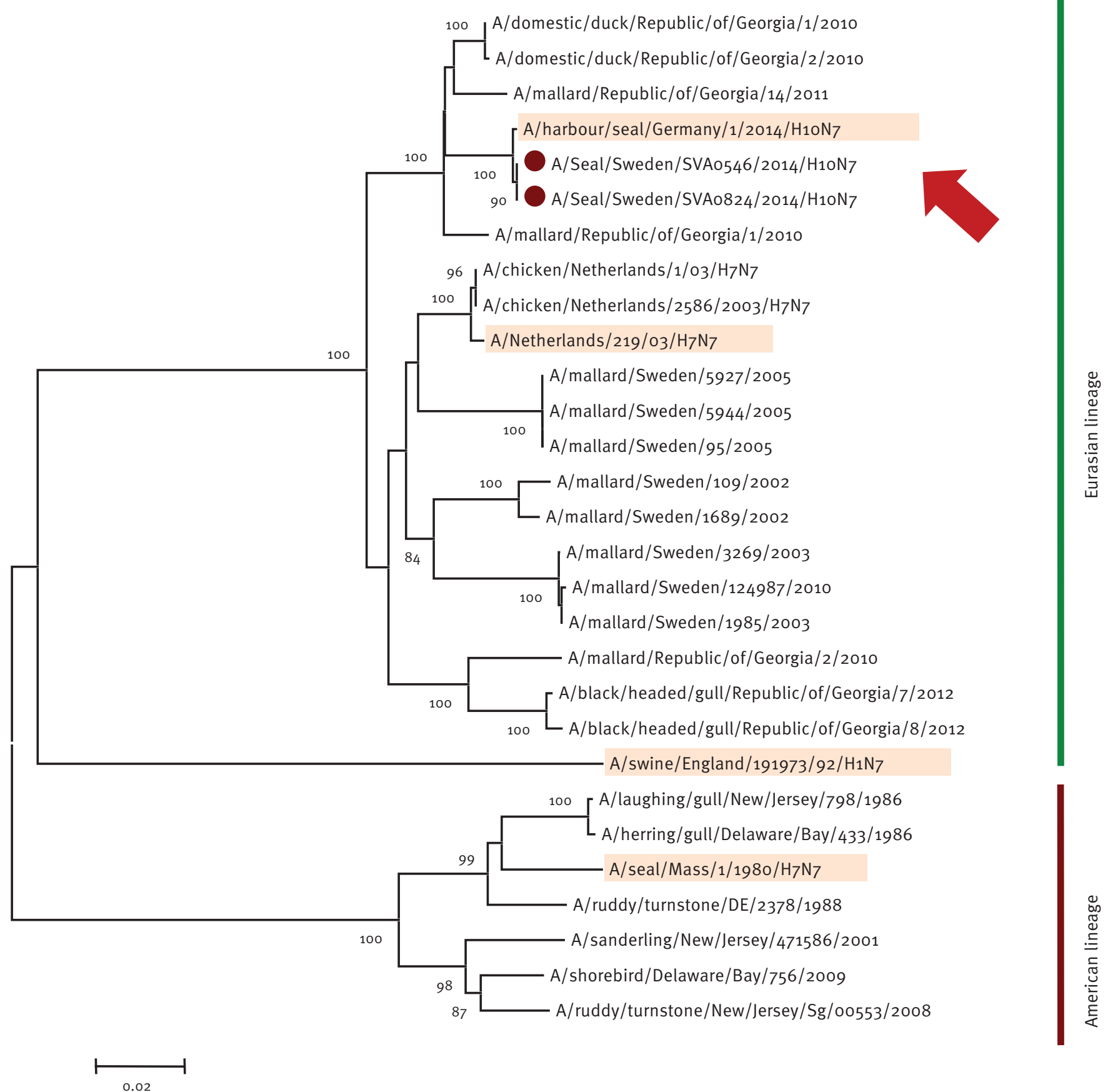

The protein coding region tree was generated by neighbour-joining analysis with the Tamura-Nei $\gamma$-model, using MEGA 6.0. Numbers below key nodes indicate the percentage of bootstrap values of 2,000 replicates. Isolates sequenced in this study are indicated by a red dot. Taxons leading to $\mathrm{A}\left(\mathrm{H}_{1} \mathrm{O}\right)$ subtype viruses detected in mammalian species are highlighted in pink. The nucleotide sequences obtained in the present study are available in the Global Initiative on Sharing All Influenza Data (GISAID) under HA gene accession numbers EPI545212 (Seal 1) and $\mathrm{EPI} 547696$ (Seal2). For the phylogenetic analysis, relevant sequences were obtained from the influenza database of the National Center for Biotechnology Information (NCBI), and the HA and NA genes of A/harbour seal/Germany/1/2014/H10N7 were obtained from GISAID's EpiFlu database.

province, sampled in the field, and lung tissue was submitted to SVA.

\section{Pathological findings}

Formalin-fixed tissues from both seals were processed by routine histological examination [4]. Seal 1 was a 12 year-old adult male in slightly impaired nutritional condition. Widespread emphysema was observed within the mediastinum and thoracic musculature, and bronchial and mediastinal lymph nodes were enlarged and oedematous. Lungs were diffusely firmer than normal, consistent with interstitial pneumonia, and the spleen was enlarged. Severe acute necrosuppurative pneumonia with widespread effacement of 
Haemagglutination inhibition and neuraminidase inhibition tests of one influenza virus isolated from a seal using monospecific reference antisera, Sweden, August 2014

\begin{tabular}{|c|c|c|c|}
\hline \multicolumn{4}{|c|}{ A/Seal/Sweden/0546/2014 } \\
\hline \multirow{28}{*}{ 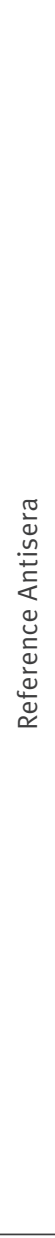 } & \multicolumn{3}{|c|}{ Heamagglutination inhibition } \\
\hline & $\mathrm{H}_{1} \mathrm{~N}_{2}$ & A/DK/HONG KONG/196/77 & $\ll 1: 2$ \\
\hline & $\mathrm{H}_{2} \mathrm{~N}_{3}$ & A/DUCK/GERM/1215/73 & $<1: 2$ \\
\hline & $\mathrm{H}_{3} \mathrm{~N}_{2}$ & A/Turkey/Eng/69 & $<1: 2$ \\
\hline & $\mathrm{H}_{4} \mathrm{~N} 6$ & $\mathrm{~A} / \mathrm{DK} / \mathrm{CZECH} / 56$ & $\ll 1: 2$ \\
\hline & $\mathrm{H}_{5} \mathrm{~N}_{1}$ & $\mathrm{~A} / \mathrm{CK} / \mathrm{SCOT} / 59$ & $\ll 1: 2$ \\
\hline & $\mathrm{H} 6 \mathrm{~N} 8$ & A/TURKEY/CANADA/63 & $<1: 2$ \\
\hline & $\mathrm{H}_{7} \mathrm{~N}_{7}$ & A/TKY/ENG/647/77 & $1: 32$ \\
\hline & $\mathrm{H}_{8} \mathrm{~N}_{4}$ & A/TK/ONT/6118/68 & $\langle 1: 2$ \\
\hline & $\mathrm{H}_{9} \mathrm{~N}_{2}$ & A/CKKOR/99029/99 & $<1: 2$ \\
\hline & $\mathrm{H}_{10 \mathrm{~N}} 9$ & $\begin{array}{l}\text { A/S.AFRICA/EG. } \\
\text { GOOSE/238/98 }\end{array}$ & $1: 2,048$ \\
\hline & $\mathrm{H} 11 \mathrm{~N} 6$ & A/DUCK/ENG/56 & $\langle 1: 2$ \\
\hline & $\mathrm{H}_{12} \mathrm{~N}_{5}$ & A/DK/ALBERTA/60/76 & $\langle 1: 2$ \\
\hline & $\mathrm{H} 13 \mathrm{~N} 6$ & A/GULL/MARYLAND/704/77 & $<1: 2$ \\
\hline & $\mathrm{H}_{14} \mathrm{~N} 6$ & A/MALL/GURG/244/82 & $\langle 1: 2$ \\
\hline & $\mathrm{H} 15 \mathrm{~N} 8$ & A/Duck/Australia/341/83 & $\langle 1: 2$ \\
\hline & $\mathrm{H}_{16} \mathrm{~N}_{3}$ & A/GULL/DK/68110/02 & $\langle 1: 2$ \\
\hline & $\mathrm{H}_{7} \mathrm{~N}_{1}$ & A/African Starling/Eng/983/79 & $<1: 2$ \\
\hline & \multicolumn{3}{|c|}{ Neuraminidase inhibition } \\
\hline & $\mathrm{H}_{7} \mathrm{~N}_{1}$ & A/African Starling/Eng/983/79 & Negative \\
\hline & $\mathrm{H}_{1} \mathrm{~N}_{2}$ & A/DK/HONG KONG/ 196/77 & Negative \\
\hline & $\mathrm{H}_{2} \mathrm{~N}_{3}$ & A/DUCK/GERM/1215/73 & Negative \\
\hline & $\mathrm{H}_{8} \mathrm{~N}_{4}$ & A/TK/ONT/6118/68 & Negative \\
\hline & $\mathrm{H}_{12} \mathrm{~N}_{5}$ & A/DK/ALBERTA/6o/76 & Negative \\
\hline & H11N6 & A/DUCK/ENG/56 & Negative \\
\hline & $\mathrm{H}_{7} \mathrm{~N}_{7}$ & A/TKY/ENG/647/77 & Positive \\
\hline & $\mathrm{H}_{15} \mathrm{~N} 8$ & A/Duck/Australia/341/83 & Negative \\
\hline & $\mathrm{H} 11 \mathrm{Ng}$ & A/Mallard/Sweden/F1205/05 & Negative \\
\hline
\end{tabular}

normal architecture was seen microscopically. Routine bacterial culture of the lung, bronchial lymph node and spleen yielded moderate to abundant growth of Escherichia coli in almost pure culture.

Seal 2 was severely decomposed and only a small sample of lung was available for examination. Despite the loss of cellular detail from autolysis, alveolar wall thickening supportive of an interstitial pneumonia was detected microscopically. Autolysis and limited material precluded investigation of concurrent bacterial pneumonia.

\section{Virology}

RNA was extracted from lung tissues and tested initially by real-time reverse-transcription polymerase chain reaction ( $r R T-P C R)$ targeting the matrix protein gene of avian influenza A viruses (AIV) [5] and the haemagglutinin gene of phocine distemper virus (PDV) [6]. AIV RNA was detected in lung tissue of both Seals 1 and 2, while PDV was not detected. RT-PCR for detection of the haemagglutinin (HA) and neuraminidase (NA) genes of IAV was performed using segment-specific but subtype-universal primers as previously described [7]. The nucleotide sequence A/ Seal/Sweden/SVA0546/2014 (Seal 1) and A/Seal/ Sweden/SVA0824/2014 (Seal 2), which were detected 4.5 months apart, possessed almost identical HA and NA genes ( $99 \%$ identity). The HA and NA genes clustered within the Eurasian avian lineage (Figure 2 and 3) showing $99 \%$ nucleotide similarity to the HA and NA genes of a German seal isolate from September 2014, A/harbour seal/Germany/1/2014/H10N7, using the BLAST programme of the Global Initiative on Sharing All Influenza Data (GISAID)s EpiFlu Database (http:// www.gisaid.org). These sequences were obtained from GISAID's EpiFlu database (details are given at the end of the article). The amino acid sequence at the cleavage site in the HA molecule was PELVQGR/GLF, characteristic of low-pathogenicity AIV.

IAV was isolated from lung tissue of Seal 2 using specific pathogen-free (SPF) embryonated hens' eggs (EE) as previously described [8]. The allantoic fluid from the first passage in the EE showed haemagglunitating activity (HA > 256). The haemagglutinating agent could be further identified as influenza $A\left(\mathrm{H}_{10} \mathrm{~N}_{7}\right)$ using specific reference antisera for $\mathrm{H}_{1}-\mathrm{H}_{16}$ and $\mathrm{N}_{1}-\mathrm{N}_{9}$ in haemagglutination inhibition and neuraminidase inhibition test (Table) [9]. The virus had an intravenous pathogenicity index [8] value of 0.00 , confirming the low pathogenicity of the virus for chickens.

\section{Discussion}

Although IAV infection has been reported in a variety of species of marine mammals including seals [10-12], this is, to our knowledge, the first published report of AIV isolation from seals in Europe and the first time that the $\mathrm{H}_{10}$ subtype has been detected in seals anywhere. It provides evidence that the $\mathrm{H}_{10} \mathrm{~N}_{7}$ subtype was associated with an outbreak of seal mortality in Europe. Although we detected the virus in only two affected seals, media reports support $\mathrm{H}_{10 \mathrm{~N}} 7$ involvement in seal mortality events in Denmark, Germany and the Netherlands, as the virus was isolated from numerous dead seals [1-3].

As in AIV-associated mortality events in seals in the United States (US), Seal 1 suffered from a concurrent bacterial pneumonia [10]. Viral damage to physical components of the respiratory immune system is thought to allow secondary invasion of opportunistic bacteria. Limited quantity and quality of material from Seal 2 precluded investigation of bacterial infection.

Through phylogenetic analyses, we showed that this virus is genetically closely related to Eurasian AIVs from wild and domestic birds (Figure 2 and 3). IAVs are known to be circulating at high prevalence in European aquatic birds [13], supporting initial introduction of the $\mathrm{H}_{10} \mathrm{o}$ virus in seals from aquatic birds in Europe. The seals probably contracted the virus through direct or indirect contact with wild birds or their droppings. Interspecies transmission from birds to seals 
requires concurrent alignment of numerous factors and although it occurs, it is not likely to occur often. There was an interval of 4.5 months between Seal 1 and Seal 2, suggesting that the virus was circulating among the seal population during this entire time.

From a public health perspective, extended circulation within a mammalian host not only demonstrates that this strain is capable of infecting and circulating in mammals, but it increases the opportunity for mutations to occur that may facilitate human infection. For example, the $\mathrm{H}_{3} \mathrm{~N} 8$ strain from harbour seals in the US had recent mutations that are known to make influenza viruses more transmissible and cause more severe disease [12]. It also has the ability to target the SAa2,6 receptor found in the human respiratory tract, an adaptation known to increase transmission and virulence in mammalian hosts [12]. In addition, some avian $\mathrm{H} 10$ viruses, including those isolated from farmed mink (Mustela vison) ( $\left.\mathrm{H}_{10} \mathrm{~N}_{4}\right)$, humans ( $\left.\mathrm{H}_{10} \mathrm{~N}_{7}, \mathrm{H}_{10} \mathrm{~N} 8\right)$ and pigs ( $\mathrm{H}_{10 \mathrm{~N}_{5}}$ ) (Figure 2 ) had the unique ability to cause severe disease in mammalian species without prior adaptation in poultry, supporting the hypothesis that these viruses in particular might pose a threat to human health [14-20].

Outbreaks of diseases among marine mammals can also involve interaction with humans and wild and domesticated animals, therefore, circulation of AIVs in mammals may have potential implications for public health. Management of dead marine mammals is challenging and especially difficult when they carry a new pathogen with unknown infectivity for humans. We lack information on the zoonotic potential of this particular strain of AIV and highlight the need for further assessment and research regarding risks for public health. Handling and disposal of carcasses may expose people to any number of potential zoonotic pathogens. This necessitates applying the precautionary principle as well as close collaboration and sharing of responsibility and resources between agencies at the local and national level for situations in which jurisdictional boundaries are often poorly defined.

\section{Nucleotide sequences accession number}

The nucleotide sequences obtained in the present study have been made available in the database of the Global Initiative on Sharing All Influenza Data (GISAID) under accession numbers EPI545212, EPI545213 (Seal 1) and EPI547696, EPI547697 (Seal 2). For the phylogenetic analysis, relevant sequences were obtained from the influenza database of the National Center for Biotechnology Information (NCBI). We also acknowledge the authors, originating and submitting laboratories for the HA and NA sequences of A/harbour seal/ Germany/1/2014 with accession numbers EPI544351 and EPI544353 from GISAID’s EpiFlu Database.
Acknowledgements

The authors thank Anders Bergmann and Annika Strömberg from the Swedish Museum of Natural History for gross examination and sampling of Seal 1 and Malin Stenström, Swedish Museum of Natural History, for contributions to the epidemiologic investigation.

\section{Conflict of interest}

None declared.

\section{Authors' contributions}

SZ and AN conceived and drafted the manuscript. SZ carried out PCR and sequencing, performed sequence analyses, alignments, phylogenies, interpretation of data and conducted the virological laboratory investigation. AN performed the histopathological examination and interpreted data. TH and $\mathrm{CM}$ conducted the epidemiological investigation and contributed to and revised the manuscript. JFV contributed to conception, interpretation of data, and revised the manuscript. All authors have reviewed and agreed on the content of the final manuscript.

\section{References}

1. Osterath B. Hundreds of seals die of avian flu in Germany. Bonn: Deutsche Welle; 27 Oct 2014. Available from: http://www.dw.de/ hundreds-of-seals-die-of-avian-flu-in-germany/a-18023880

2. Common Wadden Sea Secretariat. (CWSS). Increased seal mortality in Denmark, Schleswig-Holstein and Lower Saxony. Wilhelmshaven: CWSS; 24 Oct 2014. Available from: http:// www.waddensea-secretariat.org/news-and-service/news/1408-11increased-seal-mortality-in-denmark-schleswig-holsteinand-lower

3. Van Jaarsveldt J. Dutch seals dying from severe flu. Amsterdam: NLTimes; 18 Nov 2014. Available from: http:// www.nltimes.nl/2014/11/18/dutch-seals-dying-severe-flu/

4. Luna LG, editor. Manual of histologic staining methods of the Armed Forces Institute of Pathology. 3rd ed. Toronto: Blakiston Division, McGraw-Hill; 1968.

5. Spackman E, Senne DA, Bulaga LL, Myers TJ, Perdue ML, Garber LP, et al. Development of real-time RT-PCR for the detection of avian influenza virus. Avian Dis. 2003;47(3) Suppl;1079-82. http://dx.doi.org/10.1637/0005-2086-47. s3.1079 PMID:14575115

6. Hammond JA, Pomeroy PP, Hall AJ, Smith VJ. Identification and real-time PCR quantification of Phocine distemper virus from two colonies of Scottish grey seals in 2002. J Gen Virol. 2005;86(Pt 9):2563-7. http://dx.doi.org/10.1099/vir.0.80962-0 PMID:16099915

7. Zohari S, Metreveli G, Kiss I, Belák S, Berg M. Full genome comparison and characterization of avian $\mathrm{H}_{10}$ viruses with different pathogenicity in Mink (Mustela vison) reveals genetic and functional differences in the non-structural gene. Virol J. 2010;7(1):145. http://dx.doi.org/10.1186/1743-422X-7-145 PMID:20591155

8. European Commission. Council Directive 2005/94/EC of 20 December 2005 on Community measures for the control of avian influenza and repealing Directive 92/40/EEC. Official Journal L 010, 14/01/2006 P. 16 - 65. Available from: http://eurlex.europa.eu/legal-content/EN/TXT/PDF/?uri=CELEX:32005Lo $094 \&$ from $=\mathrm{EN}$

9. Aymard-Henry M, Coleman MT, Dowdle WR, Laver WG, Schild GC, Webster RG. Influenzavirus neuraminidase and

\begin{tabular}{|l|l|l|l|l|l|}
\hline Segment ID & Segment & Country & Collection date & Isolate name & $\begin{array}{l}\text { Originating and Submitting } \\
\text { Laboratory }\end{array}$ \\
\hline EPI544351 & HA & Germany & $2014-10-07$ & $\begin{array}{l}\text { A/harbour seal/ } \\
\text { Germany/1/2014 }\end{array}$ & Erasmus Medical Center \\
\hline EPI544353 & NA & $\begin{array}{l}\text { Bodewes, } \\
\text { Rogier }\end{array}$ \\
\hline
\end{tabular}


neuraminidase-inhibition test procedures. Bull World Health Organ. 1973;48(2):199-202. PMID:4541685

10. White VC. A review of influenza viruses in seals and the implications for public health. US Army Med Dep J. 2013; 45-50.

11. Reperant LA, Rimmelzwaan GF, Kuiken T. Avian influenza viruses in mammals. Rev Sci Tech. 2009;28(1):137-59. PMID:19618623

12. Anthony SJ, St Leger JA, Pugliares K, Ip HS, Chan JM, Carpenter ZW, et al. Emergence of fatal avian influenza in New England harbor seals. MBio. 2012;3(4):e00166-12. 10.1128/mBio.0016612 PMID:22851656

13. Wallensten A, Munster VJ, Latorre-Margalef N, Brytting M, Elmberg J, Fouchier RAM, et al. Surveillance of influenza $A$ virus in migratory waterfowl in northern Europe. Emerg Infect Dis. 2007;13(3):404-11. http://dx.doi.org/10.3201/ eid1303.061130 PMID:17552093

14. García-Sastre A, Schmolke M. Avian influenza A H1oN8--a virus on the verge? Lancet. 2014;383(9918):676-7. http://dx.doi. org/10.1016/S0140-6736(14)60163-X PMID:24508318

15. Klingeborn B, Englund L, Rott R, Juntti N, Rockborn G. An avian influenza $A$ virus killing a mammalian species e the mink. Brief report. Arch Virol. 1985; 86(3e4):347e51.

16. Englund L, Hard af Segerstad C. Two avian $\mathrm{H}_{10}$ influenza A virus strains with different pathogenicity for mink (Mustela vison). Arch Virol. 1998;143(4):653e66.

17. Wang N, ZouW, Yang Y, Guo X, Hua Y, Zhang Q, et al. Complete genome sequence of an $\mathrm{H}_{10} \mathrm{~N}_{5}$ avian influenza virus isolated from pigs in central China. J Virol. 2012;86(24):13865e6.

18. Pan American Health Organization. Avian influenza virus A ( $\left.\mathrm{H}_{10} \mathrm{~N}_{7}\right)$ circulating among humans in Egypt. EID Weekly Updates. 20042(18). Available from: http://www.paho.org/hq/ index.php?option=com_docman\&task=doc_download\&gid=16 672\&ltemid=2518\&lang=en

19. Arzey GG, Kirkland PD, Arzey KE, Frost M, Maywood P, Conaty $S$, et al. Influenza virus A ( $\left.\mathrm{H}_{1} \mathrm{ON} 7\right)$ in chickens and poultry abattoir workers, Australia. Emerg Infect Dis. 2012; 18(5):814e6.

20. Chen H, Yuan H, Gao R, Zhang J, Wang D, Xiong Y, et al. Clinical and epidemiological characteristics of a fatal case of avian influenza A H1oN8 virus infection: a descriptive study. Lancet. 2014;383(9918):714-21. http://dx.doi.org/10.1016/S01406736(14)60111-2 PMID:24507376 